\title{
Psychological Dynamics In The Changing Of Bullying Victims Into Bullies At Student In Islamic Boarding School
}

\author{
Sigit Nugroho ${ }^{1}$, Seger Handoyo ${ }^{2}$, Wiwin Hendriani ${ }^{3}$ \\ ${ }^{1}$ Universitas Islam Riau, Indonesia \\ 2,3 Universitas Airlangga, Indonesia \\ Corresponding Email: sigit.nugroho@psy.uir.ac.id
}

\begin{abstract}
Bullying case was one of the problems conducted in school that became an international concern. Bullying occurrence in school was not limited to regular school but also in boarding school, particularly in islamic boarding school; thus, this phenomenon had a higher chance to occur in boarding school due to seniority. It was also found that the bullies were previously had the experiences as the victims. According to this phenomenon, a qualitative study was held to formulate the substantial theory about the psychological dynamics of the victim becoming bullies, particularly in islamic boarding school context. This study conducted the systematic grounded theory. The data was collected through in-depth interviews and observations toward nine main participants, and some supported participants and analyzed with constant comparative technique. The finding of this study was The Dynamic of Bullying: The Victims Become Bullies, which contained six phases: 1) Become the victims, 2) Aggrieved phase, 3) Frustration phase, 4) Maladaptive coping phase, 5) Trial phase, 6) Become the bullies. This dynamic explained the psychological dynamics in the victims who become bullies. Some interesting findings found in the fourth phase, the maladaptive coping phase, in which the victims decide whether to be adaptive or maladaptive to bullying activity. The alternate in the adaptation phase indicated that the shifting role of victims to bullies could be prevented. Psychological support programs, both preventive and curative way, could be beneficial to prevent the possibility of the victim becoming bullies. The preventive program could prevent the victims from becoming bullies, and the curative program could help the victim heal the trauma of bullying.
\end{abstract}

Keywords: Bullying, Grounded Theory, Islamic Boarding School, Victim-Bullies

\begin{tabular}{|c|c|c|c|c|}
\hline Submission & Review Process & Revised & Accepted & Published \\
\hline January 27, 2021 & $\begin{array}{c}\text { February 4, 2021- } \\
\text { November 18 2021 }\end{array}$ & November 26, 2021 & December 12, 2021 & December 29, 2021 \\
\hline
\end{tabular}

\section{Introduction}

Bullying cases often occur in schools, this making bullying a global problem. Research on bullying has also increased dramatically in the last ten years in various parts of the world. Bullying cases in Indonesia occupy the top rank reported to the Indonesian National Commission for Child Protection (KPAI), 2,473 out of 37,381 total complaints from 2011 to 2019 (KPAI, 2020). This data is also strengthened by the finding that $30 \%$ of elementary school students in Pekanbaru experience bullying (Nugroho and Fadhlia, 2011). In cases of bullying in Japan, it was found that the perpetrators of bullying were
$10.8 \%$ male and $4.1 \%$ female, while the victims of bullying were $14.5 \%$ female and $10.1 \%$ male (Mizuta et al., 2017). In Hong Kong, $20.4 \%$ of students were found to be bullies (Loke, Mak, \& Wu, 2016), 22.1\% in Iran (Rezapour, Soori, and Khodakarim, 2014), and $17 \%$ in Korea (Kim, Koh \& Leventhal, 2004). In addition, it was found Interesting that the victim tended to become the perpetrator. US Secret Service study in 2000 found that more than $2 / 3 \%(66,67 \%)$ of shooting incidents in 37 schools since 1974 were perpetrated by victims of bullying (Coloroso, 2007). Graham (2011) added that only $1 / 3 \%(33,33 \%)$ of the total students who 
were victims of bullying in grade 6 remained victims until school ended, where the number of victims dropped by $10 \%$ in grade 8 . Several other studies have also revealed that perpetrators of bullying are also victims or have previously been victims of bullying (Bloom, 2008; Koh \& Leventhal, 2004; Rezapour, Soori, and Khodakarim, 2014). Theexistence of similar traits in the form of poor social skills, low self-confidence, and poor problem-solving in perpetrators and victims is one indication of the possibility of victims becoming perpetrators (Sigurdson et al., 2015).

The phenomenon of bullying occurs on a wide scale that is not limited to a certain age groups, genders and regions. Furthermore, the phenomenon of bullying is also not limited to certain educational institutions. Several studies have found that bullying occurs not only in public schools but also in boarding schools (Pfeiffer \& Pinquart, 2014; Cross, Lester \& Mandel, 2015; Edling \& Francia, 2017). Boarding schools create susceptibility to bullying due to separation from parents, which is replaced by activities with friends within and after school (Whited, 2004). In Indonesia, the practice of boarding schools includes international-based schools, official schools, and Islamic boarding schools. In contrast to other types of boarding schools, the distinctive characteristics of islamic boarding school lie in the more dominant religious content, namely the close relationship between the student (student) and the teacher (Kiai), the submission of the student to the Kiai, the frugal and simple life, the spirit of self-help, and the spirit of helping or brotherhood (Bawani, 1993). In practice, the situation is the exact opposite. Desiree (2013) said that bullying often occurs in Islamic boarding schools in the form of physical bullying (hitting, kicking), verbal (abusive words, mockery), and exclusion. Data analysis shows that $59 \%$ of students in Islamic boarding schools experience bullying (Nugroho \& Fardhana, 2018).

Furthermore, bullying in boarding schools and Islamic boarding schools, in particular, is mainly caused by the existence of senior-junior relationships. The behavior of seniors to juniors is hazing, harsh treatment, bad calling, bothering, and so on (Basri, 2001). The senior-junior relationship breeds violence in the boarding school. Seniors who become bullies are, on average, victims of bullying from their previous seniors (Nuriana, 2015).

The paradoxical condition between the characteristics of Islamic boarding schools that emphasize religious content and the practice of students engaging in bullying is interesting to be studied more. The practice of Islamic boarding schools that instill religious values is not reflected in the aggressive behavior of students shown through bullying. Specifically, the process of knowing the psychological dynamics of bullying victims to become bullies will be the focus of discussion. These psychological dynamics can be explained by Social Learning Theory (Bandura, 1978), Social-Ecological Approach (Brofenbrenner, 2000), and Behavioral Change Theory (Rogers, 1983). In learning theory, bullying arises by observing bullying behavior through interactions in the social environment. Bullying behavior will increasingly appear if positive reinforcement or reward (Bandura, 1978).

The ecological approach explains that bullying is caused by individual characters and complex situational variables (Brofenbrenner, 2000). Behavior Change Theory explains five stages of behavior formation, namely awareness (realizing bullying), interest (paying attention to bullying), evaluation (judging excellent and wrong bullying), trial (trying bullying), and adoption (adopting bullying in behavior). The three theories can explain the psychological dynamics of bullies. However, it is still challenging to capture the 
complexity of the dynamics of the victim being the bullies, considering that the victim's character is associated with being shy, helpless, unassertive, and other characters (Rigby, 2002; Petrosino, Guckenberg, DeVoe \& Hanson, 2002). 2010). Lam and Liu (2007) show that the process of individuals becoming bullies comes entirely from bystanders. In line with this, Widiharto, Suminar, and Hendriani's (2020) research explain that victims of bullying also repay the bullying they receive. It indicates that the victim also tends to behave aggressively in responding to bullying. To find out the phenomenon of bullying victims turning into bullies requires context specifications, namely the islamic boarding school environment with specific characteristics. The analysis of the factors of islamic boarding school which are Indigenous to Indonesia and their solid religious content is also a discussion in understanding the dynamics of the emergence of bullying behavior in victims.

Several types of research on bullying cases in public schools have often been revealed by other researchers (Colorso, 2007; Barzilay et al., 2017; Mizuta et al., 2017; Loke, Mak, \& Wu, 2016; Rezapour, Soori, Khodakarim, 2014; Koh \& Leventhal, 2004) which only explains the demographics of bullies and victims of bullying and the forms of bullying in public school. Meanwhile, the research results on bullying in Islamic boarding schools have not been revealed holistically because the islamic boarding school culture tends to accept treatment and is closed to revealing things considered taboo, such as bullying. The process of victims becoming bullies in the islamic boarding school has also not been found to be discussed. Therefore, this research is a genuine scientific effort to explain the conditions of bullying in Islamic boarding schools, the phases, and dynamics of bullying, especially the change of victims of bullying into bullies.

\section{Research Methods}

This study was a qualitative study with a grounded theory approach, a qualitative research method that uses several systematic procedures to develop an action, interaction, or process-oriented theory based on data obtained from the research scene (Creswell, 2015). The grounded theory approach is considered appropriate to build a theory based on the reality of the psychological dynamics of victims becoming bullies in Islamic boarding schools.

The research implementation refers to the qualitative research steps of Hanurawan (2012), namely choosing a topic, formulating research questions, compiling research designs, collecting data, analyzing data, compiling research findings, validating research findings. More specifically, this study uses a systematic grounded approach (Strauss \& Corbin, 1998) which still allows the use of theory as a reference and data collection. The main participants in this study were students who were victims of bullying at the Islamic boarding school. At least they had entered the second year of studying at the islamic boarding school at the aliyah level and had been bullied more than once (eight people). The secondary sources were alumni of a boarding school who had been bullies (two people), a psychologist who handled bullying at a boarding school (one person), and a boarding school guard teacher at a boarding school (two people). The data in this study were collected by conducting in-depth interviews with participants with the principles of dialogue and discussion to build understanding and meaning in solving problems.

Observation and document analysis were also carried out to collect research data. The data analysis technique uses constant comparative to compare events with events, events with categories, and categories with categories as the core of data analysis. 


\section{Results and Discussion}

The description of the behavior experienced and carried out is that participants receive bullying in physical, verbal, or asked to do unwanted actions. The forms of physical behavior received were while sleeping, the participants' faces were given duct tape, disturbed while sleeping, causing fightsother physical behavior in the form of deliberately burning the victim's leg, hitting, staring cynically. The bullying was also accepted in verbal forms, like evil calling with a ridiculous name. The bullies called the victim by the name of the physical deficiency that exists in him. In addition to physical and verbal behavior, participants were asked to do unwanted actions requested by seniors. For example, they were asked to help buy far away from food, and they were not given. money, they were also forced to ask for money, and they were asked to take their seniors' things.

The description of the feelings and thoughts of the participants when they become victims is that participants felt hurt and wanted to take revenge when they received bullying, but because the participants were still 'new kids' or junior students, they only obeyed the wishes of the bullies and surrendered. After that, the participants and their playmates planned to take revenge, but it did not happen. When planning revenge, participants gathered with friends who had been bullied. They then shared stories about their treatment and discussed their behavior when getting revenge. This meeting gives participants some support and begins to build courage. In the end, the participants could not take revenge on the bullies but instead took revenge on a classmate who had just entered the Islamic boarding school. When the participant becomes the doer, the participant behaves like someone with great power. Participants feel afraid but angry when they receive treatment from seniors. This fear is due to many seniors' bullying and obedient attitude to their elders.
However, they are also angry because they do not accept being treated arbitrarily.

Description of the situation and condition of the participants when they were bullied: The bully happened not long after the participant officially became a boarding school student. Bullies tend to choose victims who are younger than them and classmates. Bullying was carried out in places far from the supervision of teachers and guards. The scene of bullying is usually done in the dormitory halls, behind the mosque, and in classrooms. The bullying usually occurred at night after study hours, after Isha prayers, or in the morning before class started. Bullies usually do the bullying along with their friends.

In this study, there were six phases of the dynamics of changing from victims into bullies. The first phase, Become the victims, students being a victim of bullying. New students at the islamic boarding school experience various forms of physical and verbal bullying. Physical aggression can be in the form of beatings, for example, while verbal aggression can be mocking for various reasons. Another form is that students were forced to do things they do not like, such as doing silly actions that are usually done in accepting new students. Status as new students made the students follow the orders they received.

Aggrieved Phase is the second phase. In this phase, psychological reactions appear, such as anger, disappointment, wanting revenge, fear, or feeling helpless. Aggrieved phase is the starting point for the emergence of negative emotions in the victim, marked by the appearance of revenge after getting bullied in the form of physical, verbal, or blackmail. The movement of emotions towards negative is triggered by negative affect and cognition after the victimization phase. It will be one of the determining factors for the victim to become a bully or not. Negative emotions will be more intense, persistent, or even decreased in each 
dynamic phase of the change from the victim to the bullies.

The third phase is the Frustration phase, which is about affective and cognitive reactions to revenge from the previous phase. In the frustration phase, the victim's response to the bully received shows a variety of affective and cognitive reactions, which are the accumulation of revenge from the bullying that has been obtained. Some junior students as victims understand and feel that bullying behavior is unpleasant. The victimized students will spend their days at the islamic boarding school under the existing bullying conditions. It is reinforced by the slight possibility of changing schools due to the costs incurred during the education process at the islamic boarding school. The emotional condition of students who are synergistic between perceptions and behavior towards bullying tend to experience a decrease in negative emotions. This synergy is marked by the perception of students who believe that bullying is an unpleasant thing indicated by non-bullying behavior. This emotional decline can also lead to something useful, such as attending extracurricular activities at school. This process indicates a rationalization by the victim students of the situation experienced, including the bullying experienced, the problematic situation of changing schools, and other conditions.

Meanwhile, some victims of bullying consider bullying behavior as commonplace in Islamic boarding schools done by senior students, even though cognitively and affectively they do not like and accept the bullying condition. It allows for branching of perceptions in the victim's self regarding the bullying condition, especially if conditions support the victim's students to release their revenge aggressively. Hostile emotional conditions are increasingly intense in students who have a paradoxical perception and behavior towards bullying. Students who continue to build this paradox tend to lead to maladaptive coping compared to students who have synergistic perceptions and behaviors. An increase in negative emotions can lead to destructive things, such as depression, low self-esteem, and juvenile delinquency.

The fourth phase is Maladaptive coping phase, which includes learning to feel safe and observing the rewards of bullying. The victim began to adapt incorrectly or maladaptively with a group of senior students who were bullies. The maladaptive coping phase with the senior student group is because the victim is worried about the possibility of bullying that will be experienced again. However, some of the victims began to participate in bullying with the groups they engaged in it. They are based on the need for teaching junior students to be more polite to seniors, mainly because they have experience as juniors who have been "taught" by previous seniors. Student victims will further develop a superior attitude by reinforcing conditions like negative affect and cognitive dissonance. They will decide to join a bullying group, potentially bullying other students. This maladaptive group of junior students has the potential to decide to bully. At this stage, negative emotions will be more intense, becoming a driving force for students to identify themselves with the bullying group. Individuals wait to decide to get out of bullying or become part of the bullies but will increasingly lead to bullying by the presence of seniority from younger classmates or victims of bullying (external or environmental) or individuals get social learning (social learning) by imitating the bullying behavior (internalization).

Meanwhile, the research data shows that the adaptation conditions are different from the junior students who are victims of bullying. Some other victims desire to retaliate for bullying behavior but choose to ignore the bullying condition because they feel sorry for the future victim (junior students), so they 
decide not to bully other students. In other words, some victims of bullying do not become bullies and fit into the category of being able to adapt to the conditions of experiencing bullying victims and decide not to become bullies. In principle, Affection and cognitive are essential indicators that have implications for the ability of junior students to adapt appropriately (adaptively) to the bullying they experience. Adaptive junior students have an urge or desire for revenge, but junior students as victims try to behave like when they get bullied. The coping mechanism that is carried out is laughing when there is an act of bullying that befalls another person. In addition, some victims did not engage in bullying behavior, thus forming a different cognitive dynamic. Then, some of the bullying victims with cognitive coping mechanisms decided to avoid bullying. The accumulation of constructive Affection and cognition allows students to adapt appropriately so that the movement of negative emotions regresses, although all students who are victims experience negative emotions from the revenge they feel when they get bullied.

To get to the fifth phase called Trial phase, it is necessary to strengthen internally (superior position or feeling as a senior, confident) and externally (supportive environment). The decision to bully is a twoway relationship that includes the individual, the environment, and the bullying behavior. Experience has a role in the cognitive and affective factors of bullies. This experience includes behavior received from family, teachers, and seniors. The current situation and conditions (while at the islamic boarding school) also influence bullying. Research data shows that negative Affection in the form of revenge and accumulation of fear, the learning process for victims who are members of senior bullying groups, finding a sense of security in bullying groups, and erroneous social learning coping mechanisms (cognition) are factors and components that have implications for the condition. Maladaptive, and finally, the junior students enter the trying phase. In addition, environmental factors in the form of an environment that is quiet from supervision and unassertive juniors can provide opportunities for bullying behavior to emerge. Then, the bullies themselves can strengthen or weaken the emergence of bullying behavior that comes from the environment (external).

If the supporting factors are more significant, the individual will begin to enter the early stages of being bullies. When an individual begins to enjoy rewards as a powerful individual, receives recognition from the environment, moral justification (that bullying a junior is a common thing), bullying, and releasing negative emotions that have been experienced as a victim, they have entered the final phase, which is Become the bullies. Psychological conditions arise in the form of the assumption that bullying positively impacts changing people as a participant's affection condition. Lack of empathy for other students who are bullied with erroneous cognitive understandings is common for bullies, namely the belief that bullying is effective in making other students aware of following the wishes of senior students as bullies. The existence of imitation or modeling formed from the release of pent-up resentment causes a sense of satisfaction in the bullies when carrying out bullying behavior in the form of unpleasant actions. Imitation or modeling arises because there is no significant punishment for bullies based on their observations of seniors and peers who then decide to become bullies. This attitude arises from an inability to take revenge on the bullies.

In addition, psychological conditions in the form of cognition (understanding) that bullying has become a islamic boarding school tradition make this role attached to a senior's status. The cognition develops an understanding that bullying is a tradition that 
must be maintained continuously. The research data also reflects a component of cognitive misunderstanding (distortion) as a repetition of habits (traditions) to get recognition in the form of appreciation by junior students.

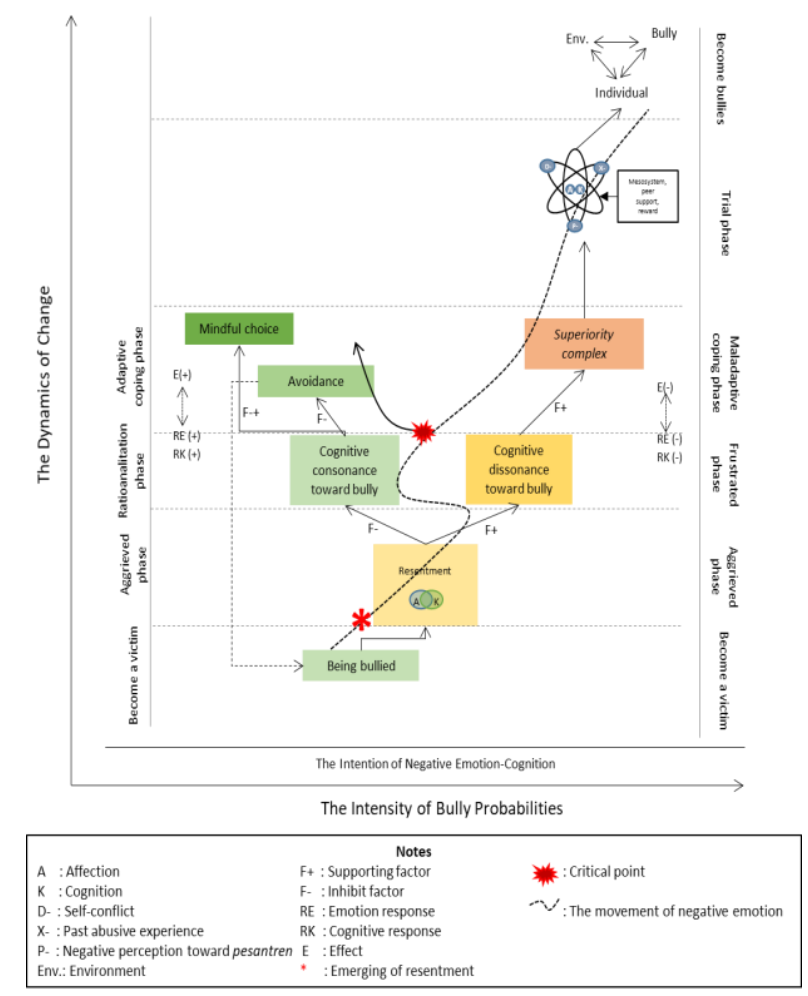

Figure 1. The Dynamic of the victim become the bullies

The new findings in this study are in the Maladaptive coping phase as a fundamental theoretical stage in providing a preventive and curative approach to students who are victims of bullying. Student, as individuals, can be prevented from being bullies if they get assistance during this phase. Psychological assistance can be provided in preventive programs to become bullies and curative programs to help recover from the trauma of bullying.

Psychological conditions experienced by students who are victims of bullying, including reinforcement in the form of the assumption that bullying has a positive impact on changing people as a participant's affection condition. The research data results also show low empathy for other students who are bullied due to cognitive misunderstanding, namely the belief that bullying is effective in making other students obey the bullies. Then the imitation formed from the release of pent-up revenge impacts the bullies a feeling of satisfaction when doing bullying behavior in the form of unpleasant actions. This behavior arises from an inability to take revenge on a senior or bully. Psychological conditions in the form of cognition understand that bullying has become a islamic boarding school tradition so that this role is attached to the status as a senior. Then the cognition develops an understanding that bullying is a tradition that must be maintained continuously. Here, there is no inconsistency between the negative consequences (affection and cognition) experienced when being a victim and current behavior in bullying the juniors. It is known as cognitive dissonance, namely the condition of individuals who behave contradictory to the beliefs and values espoused (Festinger, 1957). Cognitive 
dissonance is also reinforced by the presence of misunderstanding component as a repetition of habits (traditions) to get recognition in the form of appreciation by junior students with recognition as reinforcement that is expected to appear when bullying. The form of reinforcement that is expected is to be respected and appreciated by junior students or victims. This reinforcement raises hopes and desires as the basis for justification for bullying the victim. A strong desire for recognition provides additional reinforcement for bullying. Adler's concept of superiority complex (Feist and Feist, 2018), namely feelings of superiority from others coping with the individual's past inferiority, is found in this dynamic. The superiority complex that arises in the victim being the bullies is the urge to compensate himself as a weak victim in the past by being a solid person and expressing it to a weak person like himself in the past.

Regarding social learning theory, victims are indicated to experience moral disengagement according to four stages, namely 1) reconstructing a behavior so that it is not considered immoral; 2) reduced sense of ownership; 3) failing to see the consequences of actions taken or actions that were not taken; and 4) changing the victim's perspective on certain behaviors (Knoll et al, 2016). According to these stages, at first, the students acted as if bullying was not a moral violation, marked by the presence of the reason for "giving manners lessons" to juniors as a basis for bullying. Second, students reduce their involvement or role in the institution where they are located (in this case, islamic boarding school), including humanitarian activities such as loving and respecting others that are taught in islamic boarding school. Third, students fail or refuse to understand the consequences of bullying, which is marked by cognitive dissonance in students, leading to bullying behavior. Fourth, student changes the victim's perspective on the act, for example, by convincing the victim that they deserve to be bullied.

Several types of research on bullying in the previous findings show a relationship between several factors in a bullying model. One of the social-ecological perspectives by Bronfenbrenner explains that children's behavior will be influenced by the presence of micro-systems, mesosystems, ecosystems, and macrosystems. The child, as the center, is surrounded by an environment that will influence the formation of his behavior. The component that has the most substantial influence is in the microsystem area because this component is directly related to the child. These components are parents, teachers, and people who have close relationships with children (Boemmel \& Briscoe, 2001).

\section{Conclusion}

This research produces theoretical and practical implications. The findings of this study can be categorized as a substantive theory about the Dynamics of Bullying Victims Become Bullies, which are sequential and have a certain plot (stages theory). This substantive theory can be used to explain theoretical aspects of the dynamics of bullying victims becoming bullies. The findings in the study also indicate the need for teachers and parents provide knowledge on the Dynamics of Bullying of Victims to Bullies. The provision of knowledge can be formulated in a debriefing module that applies to teachers and parents of students before students enter boarding schools or schools with dormitory facilities. When the teaching and learning process occurs in Islamic boarding schools, teachers and students need assistance from experts such as psychologists and counselors. This assistance can be realized in the form of a Prevention and Counseling Unit based on the substantive theory found in this study. Various stakeholders or decision-makers can optimize efforts to prevent victims from becoming 
bullies in policies that involve teachers, parents, students, and experts. With this policy, the practical implications or impacts of the findings in this study can be applied optimally.

\section{References}

Basri, H. (2001). Sejarah pertumbuhan dan perkembangan lembaga-lembaga pendidikan Islam di Indonesia. Jakarta: Grasindo.

Bawani, I. (1993). Tradisionalisme dalam pendidikan Islam: studi tentang daya tahan islamic boarding school tradisional. Al-Ikhlas.

Bloom, A. (2008). Bullying policies miss the point. Times Educational Supplement, 4783, 30 .

Boemmel, J., \& Briscoe. J. (2001) Web quest project theory fact sheet of urie bronfenbrenner.

Brofenbrenner, K. (2000). Uneasy Terrain: The Impact of Capital Mobility on Workers, Wages.

Coloroso, B. (2007). Stop Bullying (Memutus rantai kekerasan anak dari prasekolah hingga smu). Jakarta: PT. Ikrar Mandiri abadi.

Creswell, J.W. (2015). Penelitian Kualitatif dan desain riset. Yogyakarta: Pustaka Pelajar.

Cross, Lester, \& Mandel. (2015). A Longitudinal Study of the Social and Emotional Predictors And Consequences Of Cyber And Traditional Bullying Victimization. International Journal of Public Health, 60 (2).

Desiree. (2013). Bullying di islamic boarding school. Jurnal Psikologi. FSIP_UI.

Edling, S., \& Francia, G. (2017). Children's rights and violence: A case analysis at a Swedish boarding school. Sage Journal, 24, 51-67.

Feist, J., Feist, G. (2018). Theories of Personality, 9th ed (9). : McGraw-Hill International Editions.
Festinger, L. (1957). A theory of cognitive dissonance. Stanford University Press.

Graham, S. (2011). What educators need to know about bullying. Educational Horizons, 89, 12-15.

Hanurawan, F. (2012). Qualitative Research in Psychology: Journal of Educational, Health and Community Psychology, 1, (2), 120-132

Kim, Y, S., Koh, Y., \& Leventhal, B, L. (2004). Prevelence of school bullying in Korean middle school students. Archives of Pediatric and Adolecent Medicine, 158, 737-741.

Knoll, M., Lord, R. G., Petersen, L. E., \& Weigelt, O. (2016). Examining the moral grey zone: The role of moral disengagement, authenticity, and situational strength in predicting unethical managerial behavior. Journal of Applied Social Psychology, 46(1), 65-78

Komisi Perlindungan Anak Indonesia. (2020). Sejumlah Kasus Bullying Sudah Warnai Catatan Masalah Anak di Awal 2020, Begini Kata Komisioner KPAI. Indonesia: KPAI.

Lam, D.O.B \& Liu, A.W.H. (2007). The path through bullying - A process model from the inside story of bullies in Hong Kong secondary schools. Child and Adolescent Social Work Journal, 24.

Loke, A.Y., Mak, Y.W. \& Wu, C.S.T. (2016). The association of peer pressure and peer affiliation with the health risk behaviors of secondary school students in Hong Kong. Public Health 137, 113-123.

Mizuta, A. Okada, E. Nakamura, M. Yamaghuci, H \& Ojima, T. (2017). Association between the time perspective and type of involvement in bullying among adolescents: A crosssectional study in Japan. Japan Journal of Nursing Science Vol 15. Issue 2 April 2018 page156-166. 
Nugroho, S \& Fadhlia, T. N. (2011). Perilaku bullying di pekanbaru. Universitas Islam Riau.

Nugroho, S., \& Fardhana, N.A. (2018). Bullying at Islamic boarding school: A pilot study in Pekanbaru. International Journal Of Pure And Applied Mathematics, 199, 2095-2100.

Nuriana, I. (2016). Reproduksi Kekerasan Dalam Relasi Antara Mahasiswa Senior Dan Mahasiswa Junior (Studi Deskriptif Pada Pelaksanaan Orientasi Pengenalan Kampus Mahasiswa Fisip Universitas Airlangga) (Doctoral Dissertation, Universitas Airlangga).

Petrosino, A., Guckenberg, S., DeVoe, J., \& Hanson, T. (2010). What characteristics of bullying, bullying victims, and schools are associated with increased reporting of bullying to school officials? (Issues and Answers Report, REL 2010No. 092). Washington, DC: U.S. Department of Education, Institute of Education Sciences, National Center for Education Evaluation and Regional Assistance, Regional Educational Laboratory Northeast and Islands. Retrieved May 31, 2012.

Pfeiffer, J.P., \& Pinquart, M. (2014). Bullying in German boarding school : A pilot study. School Psychology International, 35, 580-591.

Rezapour, M. Soori, H. Khodakarim, S. (2014). Epidemiological pattern of bullying among school children in mazandaran province, iran. Arch Trauma Res. 2014 November; 3(4): e22551

Rigby, K. (2014). Addressing bullying in schools: theoretical perspectives and their implications. Sage Publication. 25: 287

Rogers, C.R. (1983) Freedom to learn for the 80s. Charles Merrill Publishing Company: London.
Sigurdson, J. F., Undheim, A. M., Wallander, J. L., Lydersen, S., Sund, M. (2015). The long-term effects of being bullied or a bully in adolescence on externalizing and internalizing mental health problems in adulthood. Child \& Adolescent Psychiatry \& Mental Health, 9: 42, 1-13. Strauss, A., \& Corbin, J. (1998). Basics of qualitative research: Procedures and techniques for developing grounded theory.

Widhiarto, C. A., Suminar, D. R., Hendriani, W. Identification of Victims Response to Bullying Cases: A Study of Javanese Students: Journal of Educational, Health and Community Psychology, 9 (2), 117-132

Whited, M.A. (2004). An Australian coeducation boarding school as a crucible for life: A humanistic sociological study of students' attitudes from their own memoirs. Unpublished dissertation, University of Adelaide. 